\title{
The former presence of organic matter caused its later absence: Burn-down of organic matter in oceanic red beds enhanced by bioturbation (Eocene Variegated Shale, Carpathians)
}

\author{
ANDREAS WETZEL ${ }^{1}$ and ALFRED UCHMAN ${ }^{2}$ \\ ${ }^{1}$ Geologisches Institut der Universität Basel, Bernoullistrasse 32, CH-4056 Basel, Switzerland \\ (E-mail: Andreas.Wetzel@unibas.ch) \\ ${ }^{2}$ Institute of Geological Sciences, Jagiellonian University, Gronostajowa 3a, PL 30-387 Kraków, Poland
}

Published 2018 in: SEDIMENTOLOGY, 65: 1504-1519

doi: $10.1111 /$ sed.12436

\begin{abstract}
Eocene oceanic red beds that formed in a well-oxygenated setting at low sedimentation rates below the calcite compensation depth are effectively barren of organic carbon in the present state. Recurrent distal low-erosive turbidites preserve the bioturbated zone underneath that documents seasonal and long-term fluctuating accumulation of considerable amounts of organic matter on the sea floor as evidenced by Scolicia; the producers of this trace fossil exploited nutritious organic matter conserved in turbidite-buried sea floor deposits. Over the long-term, slow average sedimentation of (hemi)pelagic oxic (red) mud led to long oxygen exposure times and low burial of organic matter. Consequently, trace fossils representing persistent sediment-feeding modes are of small size. Although the food-limited setting appears appropriate for producers of graphoglyptids, such 'stationary' burrows have not been encountered because seasonal deposition of organic matter fostered at least temporary surface layer feeding organisms, for instance producers of Nereites irregularis that intensively reworked the sediment and, hence, hindered graphoglyptid production. These findings confirm palaeoceanographic modeling results that suggest upwelling in the study area during the Eocene.
\end{abstract}

Keywords Deep-sea sediment, organic matter accumulation, sedimentation rate, trace fossils.

\section{INTRODUCTION}

The term oceanic red beds (ORB) has been introduced for sediment successions consisting of (hemi)pelagic marine deposits with a red or reddish colour (see review by $\mathrm{Hu}$ et al., 2012a, and references therein). Oceanic red beds are stained by hematite (e.g. Hu et al., 2012a), but the shape and size of hematite crystals, as well as hematite crystallinity, considerably affect hue and intensity of 'redness' as described by Hund (1966) and later confirmed by Li \& Cai (2013). Once hematite has formed, its stability increases with increasing crystal size, and even if chemical conditions change, hematite behaves rather inertly due to its low surface area (e.g. Roden \& Zachara, 1996). The formation of oceanic red beds has been the subject of increased study since 2005, as documented by a number of thematic volumes (Wan \& Sarti, 2005; Hu et al., 2009, 2012b; Wagreich et al., 2011). The debate about oceanic red bed formation continues, but the various studies agree that oceanic red beds only form if a few boundary conditions are met (Hu et al., 2012a). These boundary conditions are: (i) well oxygenated bottom water; (ii) oligotrophic surface waters allowing only low primary production; and (iii) low sedimentation rate $(<2$ to $5 \mathrm{~cm} / \mathrm{kyr}$; Wagreich \& Krenmayr, 2005). However, these factors may vary locally and regionally. 
Under such conditions, little organic matter is preserved within the sediments because residence time of organic matter within the oxygenated zone of the sea floor is so long that it becomes completely oxidized, with the exception of some organic compounds adsorbed to clay mineral surfaces (e.g. Müller \& Suess, 1979; Burdige, 2006). Modern counterparts of oceanic red beds are brownish in colour, while ferric iron is bound in hydroxides and oxyhydrates (König et al., 1997; Haese, 2006). These compounds are not very stable and dewater during diagenesis to be transformed into hematite (e.g. Raiswell \& Canfield, 2012).

Because organic matter is completely degraded, little information is preserved in the sediment record about specific depositional conditions. These conditions include: (i) fluctuation or absence of oxygenation within the sea floor; (ii) continual or seasonal delivery of organic matter to the sea floor; or (iii) whether organic matter was nutritious or refractory. Burrowing organisms, however, respond sensitively to these factors (e.g. Buatois \& Mángano, 2011; various papers in Knaust \& Bromley, 2012). Thus, trace fossils are useful in deciphering the environmental conditions of oceanic red bed formation. Nonetheless, there are only a few ichnological studies dealing with such sediments (e.g. Leszczyński \& Uchman, 1991, 1993; Leszczyński, 1993; Mikuláš et al., 2009; Wetzel \& Uchman, 2012; Reolid et al., 2015). A reason for the low number of investigations may be due to strong compaction and low colour contrast, both resulting in a low visibility of trace fossils. However, wet polished sections oriented parallel or oblique to bedding provide fairly good visibility of sedimentary structures and facilitate ichnological studies in deciphering the environmental setting even if sedimentary structures are hardly visible at the first glance (e.g. Wetzel \& Uchman, 1998a, b).

It is the purpose of this study to elucidate the conditions of ORB formation by analysing trace fossils and ichnofabrics present in the Eocene Variegated Shale in the Carpathians. Trace fossils are sensitive recorders of variations in benthic food levels and oxygenation within the sea floor and document how these factors changed during the early phase of oceanic red bed formation. As the bioturbated zone migrates upward with sedimentation, deep-penetrating burrows usually extinguish the record of the tiers above (e.g. Werner \& Wetzel, 1982; Wetzel, 1991). To access the complete information stored in the bioturbated zone, oceanic red beds with intercalated low-erosive distal turbidites were studied. Underneath the turbidites, the nearly complete previous sea floor with the bioturbated zone is preserved as so-called 'frozen tiers' (e.g. McIlroy, 2004). The trace fossils provide the best record of the environmental conditions as other fossil remains are very sparse to absent in the studied deep-marine settings below the calcite compensation depth (CCD).

\section{GEOLOGICAL SETTING}

Hemipelagic reddish deposits form a characteristic part of the Variegated Shale (Labowa Member) in the Magura Nappe of the Carpathian Flysch in Poland. The Variegated Shale deposits formed in a deep-sea basin (Magura Basin) from Lower Cretaceous to Miocene times. These sediments became dismembered from their substrate and incorporated into a pile of nappes in an accretionary wedge during the Alpine orogeny (e.g. Oszczypko et al., 2015). These mainly reddish and greenish, muddy to clayey shales are Lower Eocene or LowerMiddle Eocene in age (e.g. Książkiewicz, 1962; Oszczypko, 1991; Oszczypko et al., 2005). Variegated shales of similar age occur in the Alps, the Apennines and the Basque Basin as well (e.g. Hesse, 1975; Winkler, 1993; Bernaola et al., 2006). Variegated shales are chiefly carbonate-free or contain little $\mathrm{CaCO}_{3}$ (Leszczyński \& Uchman, 1991). During deposition of the studied variegated shale, hemipelagic background sedimentation was repeatedly interrupted by turbidite deposition. The turbidites are mainly thin-bedded and were deposited 
in a distal position probably from dilute turbidity currents (Leszczyński \& Uchman, 1991). The sandy to silty intervals appear greyish in colour due to their content of dark silicates, glauconite and greenish phyllosilicates (Leszczyński \& Uchman, 1991). At the contact between fine-grained hemipelagic deposits and turbidites, some colour variations may occur (see Leszczyński \& Uchman, 1991, fig. 8).

\section{MATERIAL AND METHODS}

A part of the Variegated Shale (Labowa Shale Member) was studied in an outcrop along the Słopniczanka River near the village of Słopnice (Fig. 1; GPS coordinates N 049 $42.8820^{\prime} /$ E $\left.020^{\circ} 20.05800^{\prime}\right)$. The studied deposits are Eocene in age, and form part of the Brodki Thrust Sheet (see Uchman, 2008). Four, ca $1 \mathrm{~m}$ thick red mudstone intervals were analysed in detail on a bed by bed scale with respect to primary sedimentary structures, trace fossils and ichnofabrics (Fig. 2). From mudstone intervals ca 5 to $10 \mathrm{~mm}$ thick, horizontally oriented slabs were taken. To obtain maximum information about bioturbational and primary sedimentary structures, slabs with surfaces parallel or oblique to bedding were polished under water using 60 grade abrasive paper. To reconstruct the three-dimensional geometry, slabs were serially grinded. After polishing, slabs were described and photographed.

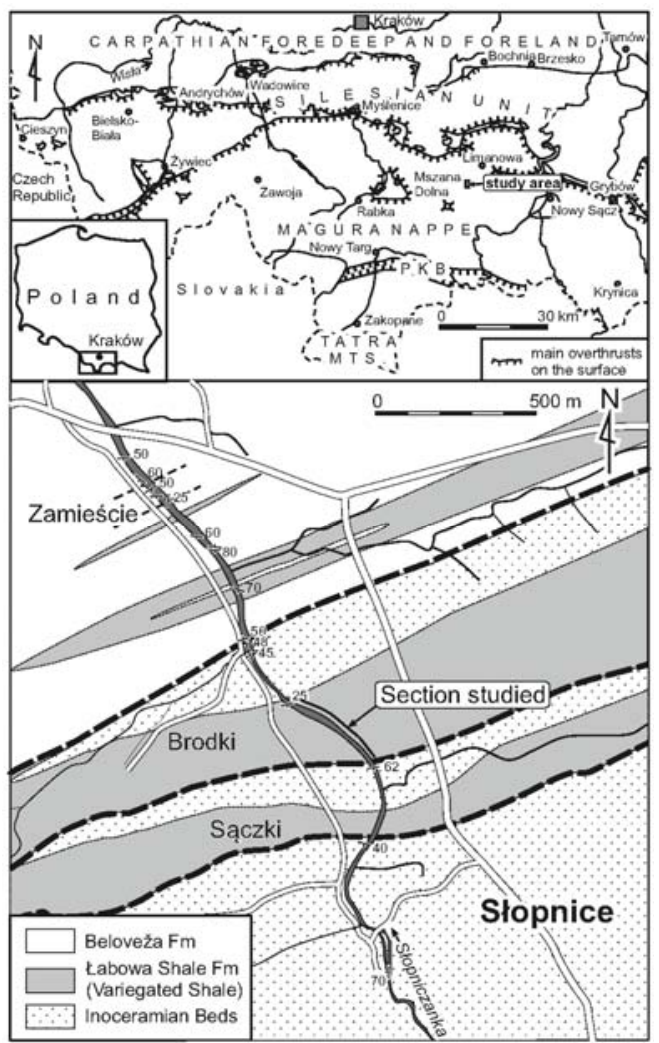

Fig. 1. Study area. (A) Location of the study area in Poland [rectangle marks the area shown in (B)]. (B) Geological domains in the area south of Kraków [small rectangle marks study area shown in (C)]. (C) Schematic geological map of the study area [small numbers refer to dip of strata (after Uchman, 2008)].
From each interval, four to eight samples were taken for geochemical analyses of red mudstone and greyish turbidites. For ca 30 samples, organic matter and carbonate content was measured using LECO RC612 equipment (Leco Corporation, St Joseph, MI, USA). The samples were stepwise heated to: (1) $110^{\circ} \mathrm{C}$; (2) $450^{\circ} \mathrm{C}$; and $(3) 1100^{\circ} \mathrm{C}$, and the corresponding loss in weight was recorded. During step (1) water evaporates; during step (2) organic matter is burnt; and during step (3) carbonate decays. To estimate the relation between organic matter content and mineral surfaces for three mudstone samples, the specific surface area was determined using a Micromeritics Gemini VII 2390t Surface Area Analyzer (Micromeritics, Norcross, GA, USA) measuring $\mathrm{N}_{2}$ adsorption at $77.3 \mathrm{~K}$ run in statistical volumetric mode (see Bertier et al., 2016). To compare the studied deposits with modern counterparts, they were virtually decompacted based on the assumption that the initial porosity at the sediment surface is in the range of modern counterparts (e.g. Schultheiss \& Gunn, 1985). 


\section{RESULTS}

Lithology

The studied variegated shales display a colour banding while red mudstone and greyish sandy-silty layers alternate. The layers appear laterally rather continuous and do not show pronounced changes in thickness. The sandy-silty layers are stained by greenish minerals such as chlorite (e.g. Leszczyński \& Uchman, 1991), and the red colour of the mudstone is caused by hematite (Dominik, 1977). The ratio between grey and red intervals is on average 1:5, but varies between $<1: 3$ and 1:8 (Fig. 2). With respect to the facies classification of Pickering et al. (1989), the studied intervals belong to Facies C2.3 'Organized sand mud couplets', while mudstones are grouped into Facies E1.2 and E1.3 'Varicoloured mud' and 'Mottled mud', respectively.

The sandy-silty beds display characteristics of turbidites while being texturally and structurally graded. Within the studied intervals, the majority (about three quarters) of the sandy-silty beds is $<2 \mathrm{~cm}$ thick, while about a quarter of them exceed 2 to $3 \mathrm{~cm}$ in thickness. Thin turbidites appear homogeneous or show faint horizontal-laminated coarse silt to fine sand grading into small-ripple lamination composed of similar-sized deposits indicating decreasing flow velocity and/or sediment concentration (cf. Mutti, 1992). Beds about 2 to 3 $\mathrm{cm}$ thick show well distinguishable parallel-laminated and ripple-laminated subdivisions, while beds $>5 \mathrm{~cm}$ in thickness exhibit well-organized parallel-laminated sand at the base.

The lower surface of the greyish turbidites is rather sharp and smooth if not accentuated by post-depositional trace fossils (see below). Predepositional burrows are rare and distinct sole marks have not been observed. The transition from the greyish sandy-silty layers to the overlying red mudstone is gradational, while bioturbated. The red mudstone intervals are completely bioturbated and average 1 to $5 \mathrm{~cm}$ in thickness. Distinct trace fossils filled with red mud constitute about a third of the fabric in red mudstone and grey layers (Fig. 3). When decompacted to porosities typical of modern deep-sea mud (75 to $80 \%$; e.g. Schultheiss \& Gunn, 1985; Kristinof \& Marketos, 2016), these layers increase by a factor of 3.5 to 4.5 in thickness (Table 1).

Table 1 Thickness of deep-sea mud layers of different thickness in the compacted and decompacted state having given porosities.

\begin{tabular}{|c|c|c|c|c|}
\hline $\begin{array}{l}\text { Actual layer thickness [cm] } \\
\text { having porosity }<10 \%\end{array}$ & 1.0 & 2.0 & 3.0 & 4.0 \\
\hline $\begin{array}{l}\text { Initial layer thickness }[\mathrm{cm}] \\
\text { having } 75 \% \text { porosity }{ }^{1} \text { ) }\end{array}$ & 3.7 & 7.4 & 11.1 & 14.8 \\
\hline $\begin{array}{l}\text { Initial layer thickness }[\mathrm{cm}] \\
\text { having } 80 \% \text { porosity }{ }^{2} \text { ) }\end{array}$ & 4.6 & 9.2 & 13.6 & 18.4 \\
\hline
\end{tabular}

1) based on data of Bryant et al. (1981)

${ }^{2}$ ) based on data of Kristinof \& Marketos (2016)

Geochemical data

The red mudstone contains $3.5 \pm 1.5 \% \mathrm{CaCO}_{3}$, while Corg is $<0.1 \%$, commonly $<0.05 \%$. Greyish sandy-silty material contains in average $6 \% \mathrm{CaCO}_{3}$ (range 5 to $12 \%$ ) and $0.2 \% \mathrm{C}_{\text {org }}$ (range 0.1 to $0.4 \%$ ). Specific surface area of the red mudstone is in the range of $30 \pm 3 \mathrm{~m}^{2} / \mathrm{g}$. 


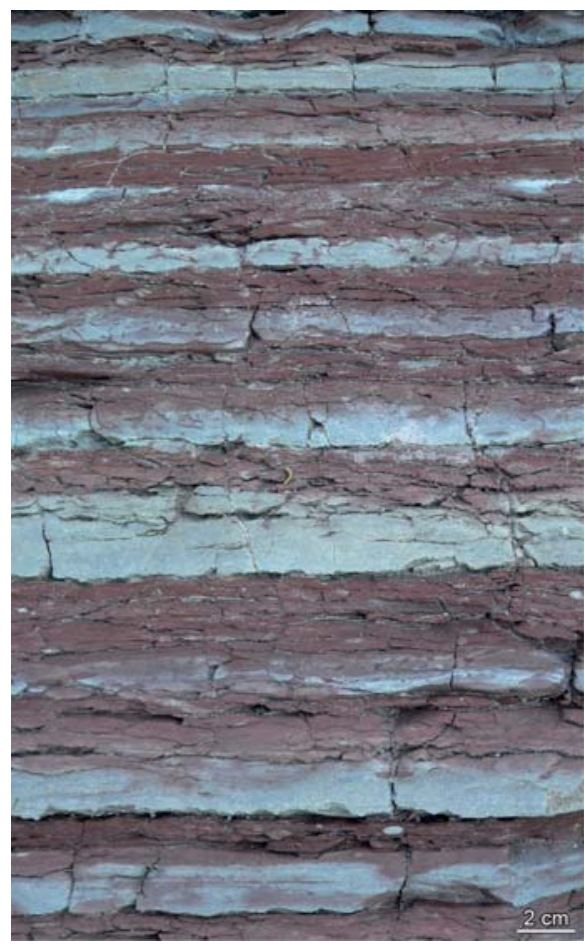

Fig. 2. Typical appearance of oceanic red beds with intercalated thin low-erosive turbidites in the studied section.

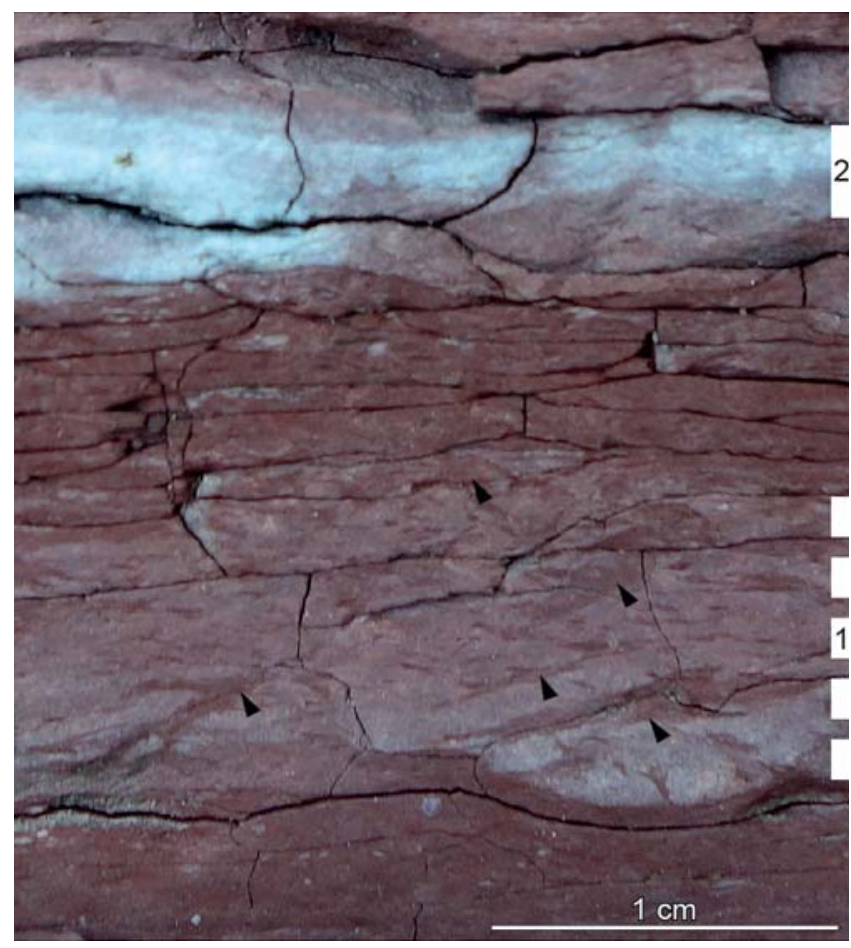

Fig. 3. Typical appearance of oceanic red beds with intercalated turbidites; the turbidite at the base $(1-$ dashed line $)$ is strongly bioturbated, note burrows. filled with red mud (arrows); centimetrethick turbidite $(2-$ solid line) is bioturbated to a lower degree.

Ichnology

The red mudstone is completely bioturbated while biodeformational structures, sensu Schäfer (1956) and trace fossils are present. At the top of each bed, the proportion of biodeformational structures is around $90 \%$, while $10 \%$ of the ichnofabric is made up of distinct trace fossils.

Downward the proportion of trace fossils increases at the expense of biodeformational structures to about $80 \%$, ca $1 \mathrm{~cm}$ above the top of turbidite sand and remains nearly constant down to the sand. Within the turbidite, the proportion of biodeformational structures is constantly only $10 \%$, while trace fossils dominate. In thick $(>2 \mathrm{~cm})$ turbidites, the proportion of trace fossils decreases downward to about $20 \%$ within the upper $2 \mathrm{~cm}$ and increases to about $40 \%$ within the basal $2 \mathrm{~cm}$ thick interval. In the case of thin turbidites, the proportion of distinct trace fossils decreases to ca 60 to $80 \%$ and remains constant, while another $10 \%$ are biodeformational structures. The greyish sandy-silty interval is bioturbated to varying degrees mainly by trace fossil producers. The trace fossils encountered are described in alphabetical order followed by a short interpretation in Table 2; they are shown schematically in Fig. 4 and in outcrop in Fig. 5.

Commonly, the trace fossils in the red mud are small, while adjacent to a turbidite relatively large Nereites irregularis, Halopoa and Scolicia can be present. At the base of a turbidite, Scolicia and Halopoa commonly occur (Fig. 5). Furthermore, a considerable proportion of the lower surface of some beds is rather smooth or exhibits tiny undeterminable burrows. Graphoglyptids have not been observed. Large Scolicia ( $>4 \mathrm{~cm}$ diameter) may show guided meanders (Fig. 6). Above, Nereites, Planolites and Avetoichnus are usually encountered. The Thalassinoides-like burrows may penetrate even more than one turbidite-red mud couplet. 
Table 2 Description and interpretation of the observed trace fossils

\begin{tabular}{|c|c|c|}
\hline $\begin{array}{l}\text { Trace } \\
\text { fossil }\end{array}$ & Description & Interpretation \\
\hline $\begin{array}{l}\text { Aveto- } \\
\text { ichnus } \\
\text { Fig. } 4 \\
\text { Fig. } 5 \mathrm{~A}\end{array}$ & $\begin{array}{l}\text { Minute complex trace fossil consisting of a } \\
\text { horizontal spiral with a simple, straight or } \\
\text { slightly curved central core; tube } 0.5-1.5 \mathrm{~mm} \text { in } \\
\text { diameter, spiral up to } 1.5-4.5 \mathrm{~mm} \text { wide and up to } \\
35 \mathrm{~mm} \text { long. }\end{array}$ & $\begin{array}{l}\text { Avetoichnus represents an agrichnion as } \\
\text { microbes are believed to be cultivated on } \\
\text { organic-rich material being packed } \\
\text { around the central tunnel within a spiral } \\
\text { (Uchman \& Rattazzi, 2011). }\end{array}$ \\
\hline $\begin{array}{l}\text { Halopoa } \\
\text { Fig. } 4 \\
\text { Fig. } 5 \mathrm{D}\end{array}$ & $\begin{array}{l}\text { Horizontal post-depositional trace preserved as } \\
\text { +hyporelief on lower surface of turbidites, } \\
\text { covered with longitudinal irregular ridges, while } \\
\text { composed of imperfectly overlapping cylindrical } \\
\text { probes; occasionally continuing into red mud } \\
\text { underneath; tube diameter } 4-8 \mathrm{~mm} \text {. }\end{array}$ & $\begin{array}{l}\text { Producers of Halopoa are deposit } \\
\text { feeders utilizing in particular sediment } \\
\text { along hemipelagite-turbidite interfaces, } \\
\text { but also in turbidite sand (Uchman, } \\
\text { 1998). }\end{array}$ \\
\hline $\begin{array}{l}\text { Nereites } \\
\text { Fig. } 4 \\
\text { Fig. } 5 \mathrm{C}, \mathrm{E}\end{array}$ & $\begin{array}{l}\text { Winding to regularly meandering, more or less } \\
\text { horizontal trail, consisting of a central back-filled } \\
\text { tunnel enveloped by a lobate zone of reworked } \\
\text { sediment; central tube } 0.5-2 \mathrm{~mm} \text { wide; } \\
\text { enveloping zone seen as such, but without } \\
\text { specific structure, about half of tube width wide; } \\
\text { Nereites occurring in } 3-8 \mathrm{~mm} \text { thick intervals at } \\
\text { the transition from sandy turbidite to red } \\
\text { mudstone; observed Nereites ascribed to } N \text {. } \\
\text { irregularis showing variations in burrowing } \\
\text { depth and connections to surface. }\end{array}$ & $\begin{array}{l}\text { Nereites producers are sediment feeders. } \\
\text { In areas affected by seasonal primary } \\
\text { production, temporarily deposited fresh } \\
\text { organic matter is utilized as additional } \\
\text { food source (Wetzel, 2002). In modern } \\
\text { sediment Nereites producers occupy a } \\
\text { shallow tier position close to redox } \\
\text { boundary utilizing still oxygenated pore } \\
\text { water (Wetzel, 2002). Nereites producers } \\
\text { may colonize event layers (e.g. Wetzel \& } \\
\text { Uchman, 2001). }\end{array}$ \\
\hline $\begin{array}{l}\text { Fig. } 4 \\
\text { Fig. 5B }\end{array}$ & $\begin{array}{l}\text { Unbranched, straight to tortuous, smooth to } \\
\text { irregularly walled burrow, circular to elliptical in } \\
\text { cross-section, of variable dimensions and } \\
\text { configurations; tube } 5-8 \mathrm{~mm} \text { wide; fill typically } \\
\text { structureless, but occasionally meniscate; fill } \\
\text { differing from host rock while enriched in red } \\
\text { mud. }\end{array}$ & $\begin{array}{l}\text { Planolites results from deposit-feeding } \\
\text { activity that leads to differentiation be- } \\
\text { tween tube fill and host sediment. If } \\
\text { producers pass through a turbidite, red } \\
\text { mud is transferred into the turbidite and } \\
\text { later sand into red mud after return into } \\
\text { red mud. }\end{array}$ \\
\hline $\begin{array}{l}\text { Fig. } 4 \\
\text { Fig. } 5 \mathrm{~F}, \mathrm{G} \\
\text { Fig. } 6\end{array}$ & $\begin{array}{l}\text { Post-depositional, bilateral-symmetrical, nearly } \\
\text { cylindrical burrow having meniscate lamellae } \\
\text { often divided into two concave sets, preserved as } \\
\text { +hyporelief on the lower surface of sandy-silty } \\
\text { turbidites; in transverse cross-section concentric } \\
\text { structure of bilobate lamellae surrounds an } \\
\text { eccentric axis; diameter } 2-4 \mathrm{~cm} \text {; two size } \\
\text { classes being present, small }(\sim 2 \mathrm{~cm}) \text { and large } \\
(\sim 4 \mathrm{~cm}) \text { diameter. Recurrently Scolicia having } \\
\text { approximately the same size are present at the } \\
\text { base of } 5 \text { to } 10 \text { successive beds, but are absent } \\
\text { below and above. }\end{array}$ & $\begin{array}{l}\text { Scolicia is produced by spatangoid } \\
\text { deposit-feeding sea urchins living in } \\
\text { sandy to silty sediments (Wetzel, 1984; } \\
\text { Bromley et al., 1997). In turbidites they } \\
\text { are interface feeders while ingesting the } \\
\text { topmost mud underneath (= uppermost } \\
\text { seafloor prior to turbidite deposition) } \\
\text { enriched in organic-matter due to } \\
\text { immediate burial. Abundance and size of } \\
\text { Scolicia increase with amount and } \\
\text { nutritious value of benthic food, } \\
\text { respectively (Kröncke, 2006; Wetzel, } \\
\text { 2008). }\end{array}$ \\
\hline $\begin{array}{l}\text { Thalassin- } \\
\text { oides-like } \\
\text { burrows }\end{array}$ & $\begin{array}{l}\text { Mostly smooth-walled, cylindrical components } \\
\text { of variable diameter constitute a 3D burrow } \\
\text { system having Y- to T-shaped branches with } \\
\text { enlarged bifurcations; vertical shafts connect } \\
\text { horizontal tube network to surface; tubes } 2-4 \\
\text { mm wide; burrows filled with red mud. Because } \\
\text { bifurcations and outer margins being not } \\
\text { typically developed burrows are called } \\
\text { Thalassinoides-like. }\end{array}$ & $\begin{array}{l}\text { Red mud fill suggests at least temporary } \\
\text { surface-feeding of producers or passive } \\
\text { infill of burrows. Deviation from } \\
\text { 'standard' Thalassinoides could result } \\
\text { from compaction effects and post- } \\
\text { depositional dissolution of carbonate (cf. } \\
\text { Archer et al., 1989; see below). Both } \\
\text { processes cause irregular deformation. }\end{array}$ \\
\hline
\end{tabular}



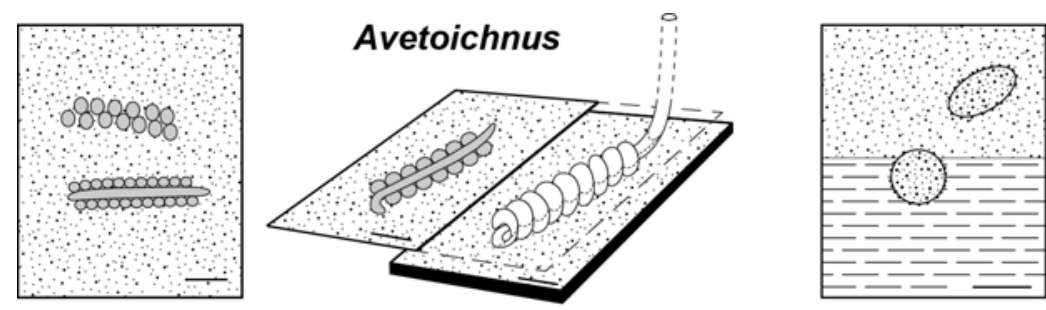

Halopoa

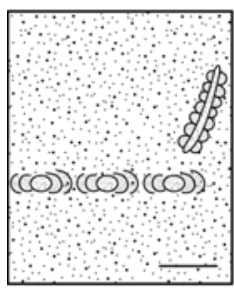

Nereites
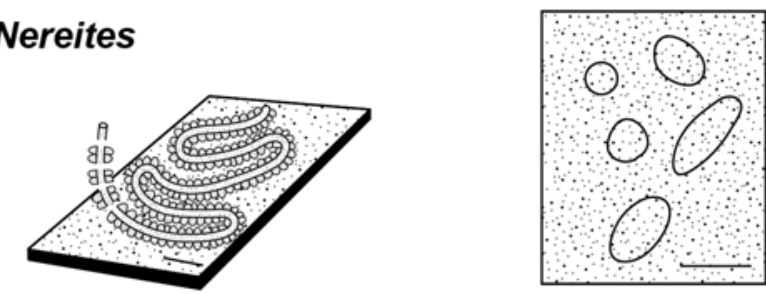

Planolites
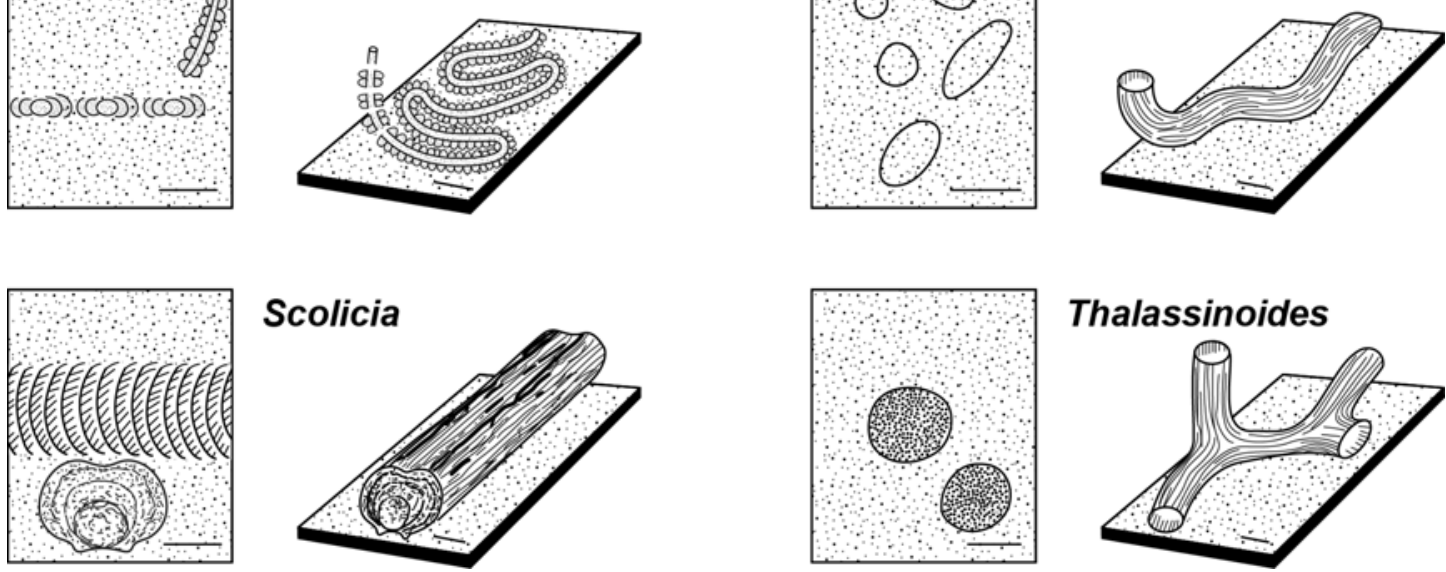

Fig. 4. Schematic drawings of encountered trace fossils, in vertical section (left) and threedimensional representation (right).

The trace fossils occupy considerably wide depth ranges within the turbidite sand-red mud couplets (Fig. 7). Producers of the Thalassinoides-like burrows maintained an open connection to the sea floor. Nereites irregularis shows variations in burrowing depth and temporary connections to the surface may occur, as indicated by rare vertical or steeply inclined burrow segments (see Fig. 5). Vertical movement is also evident adjacent to turbidites where some traces are filled by sandy-silty material displaced by burrowers thatpassed through these layers, ingested and transferred sediment. Therefore, the encountered depth zonation and cross-cutting relationships differ to some degree from the usual scheme for pelagic sediments, in which normally the deepest emplaced burrow cross-cuts all others (Bromley \& Ekdale, 1986). Scolicia is cross-cut by Halopoa and, if the sand layer is $<1$ to 2 $\mathrm{cm}$ thick, even by Nereites. The upper, muddy part of the interval occupied by Nereites, in turn, is cross-cut by Avetoichnus and Planolites. The Thalassinoides-like burrows cross-cut all other traces (Fig. 8).

A considerable proportion of the ichnofabric within the red mud is constituted by biodeformational structures (Figs 3 and 8); at the top of a mud interval, they dominate, while their proportion decreases downward. In the sandy-silty turbidites, biodeformational structures only represent ca $10 \%$ (Fig. 8). 

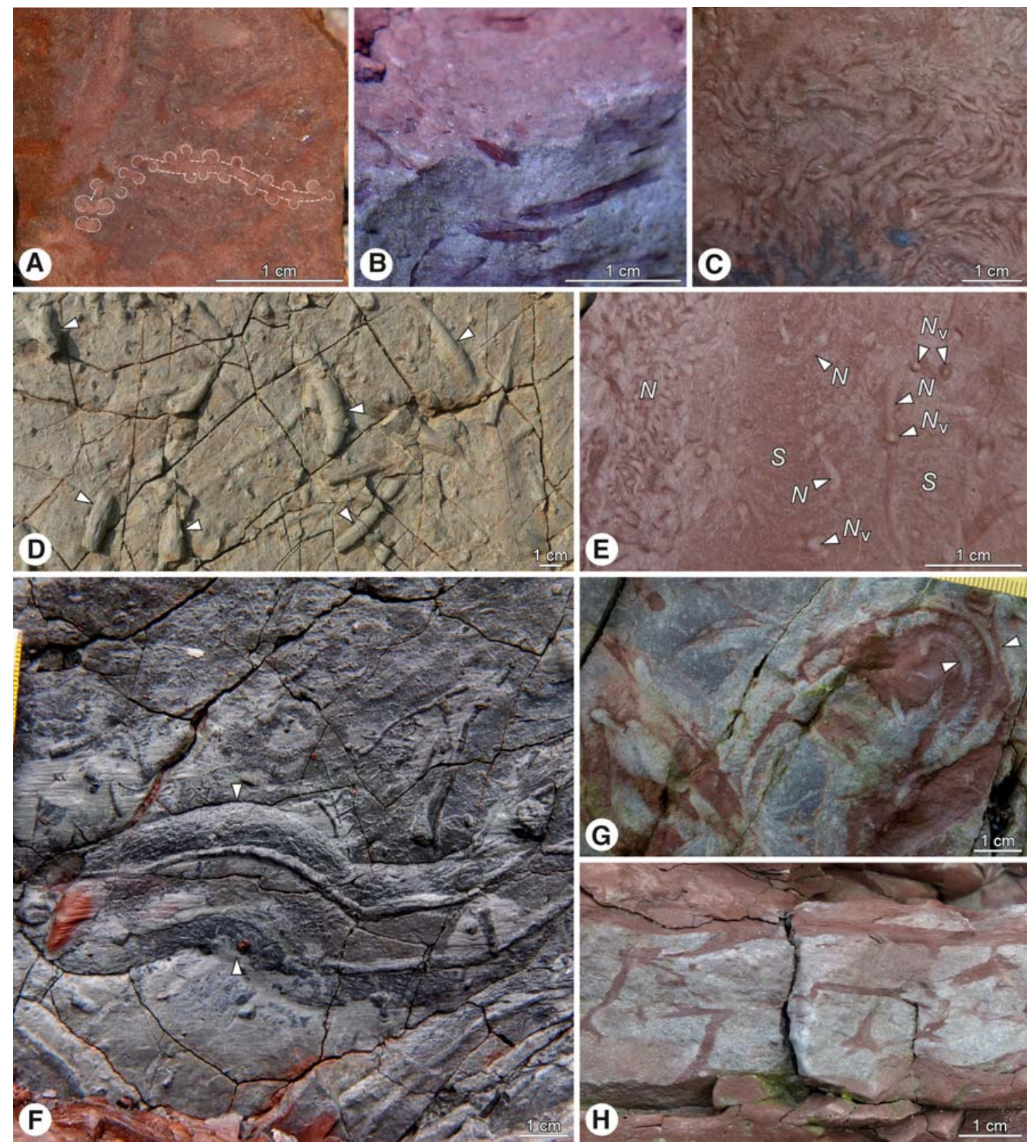

Fig. 5. Trace fossils in the field. (A) Avetoichnus in horizontal section. (B) Planolites in vertical section (dark red dots in greyish turbidite). (C) Nereites of varying sizes in horizontal section (light tube surrounded at both sides by dark halo). (D) Halopoa in thyporelief preservation (arrows) on basal turbidite bedding plane. (E) Nereites (N) in horizontal section cross-cutting Scolicia (S) and vertical and steeply inclined parts of Nereites $(N \mathrm{v}$; probably representing connection to the sea floor). (F) Large Scolicia in thyporelief preservation (between arrows) on basal turbidite bedding plane. (G) Small Scolicia in thyporelief preservation (between arrows) on basal turbidite bedding plane. $(\mathrm{H})$ Thalassinoides-like burrows filled with red mud in vertical section. 


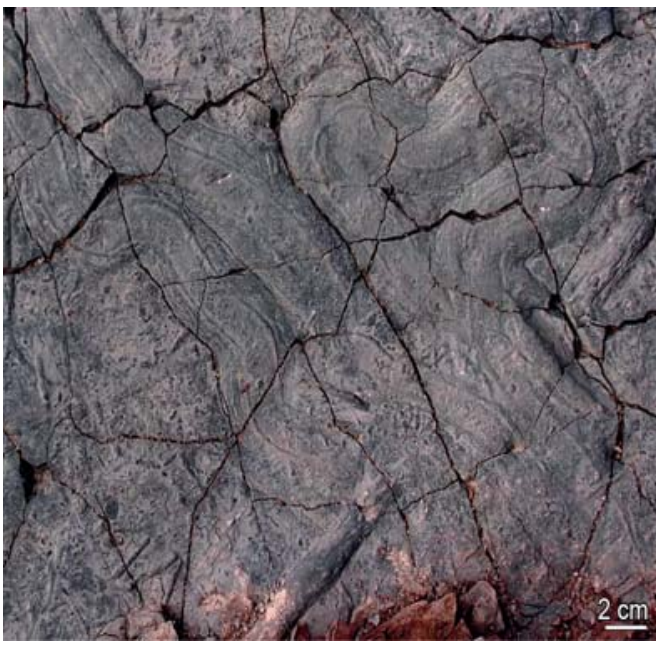

Fig. 6. Large Scolicia at the base of a turbidite showing guided meanders

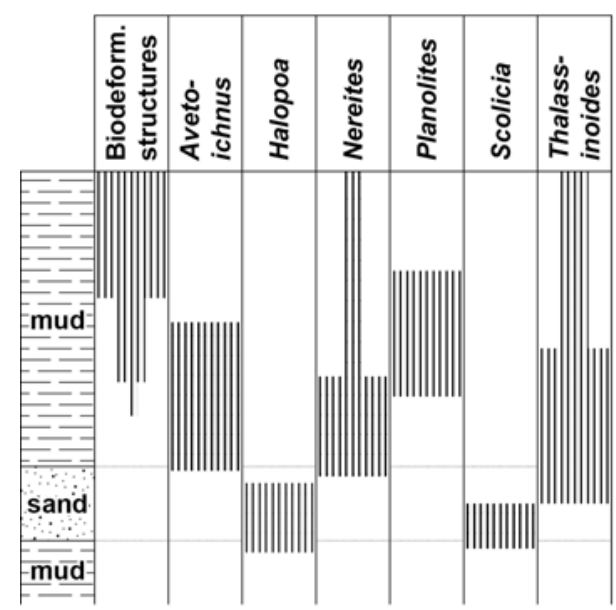

Fig. 7. Depth levels in sediment occupied by the encountered trace fossils.

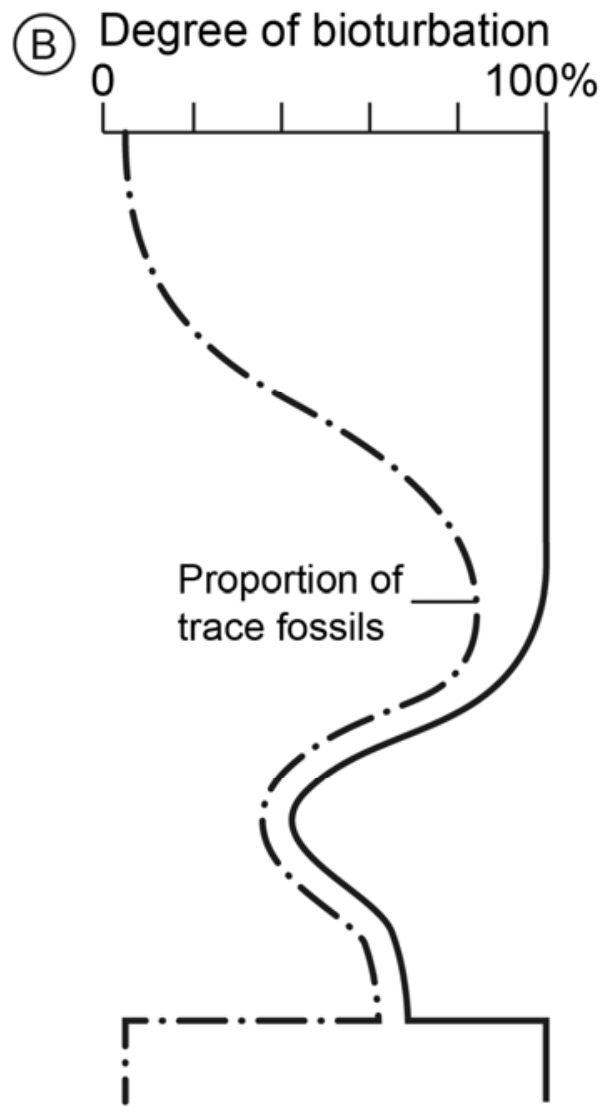

Fig. 8. Generalized scheme of the ichnofabric within a turbidite-mudstone couplet in the original, uncompacted state. (Left) Depth range of bioturbational structures within sediment and cross-cutting relationships as normally observed. (Right) Proportion of sediment occupied by trace fossils and biodeformational structures; the high proportion of biodeformational structures at the top red mud interval is typical of the (previous) near-surface level. 


\section{INTERPRETATION}

Bipartite bedding resulted from interruption of continuous hemipelagic mud accumulation by turbidity currents depositing sandy-silty layers. The sediments accumulated below CCD as evidenced by the very low carbonate content and the absence of carbonate shells in the red mudstone. The enhanced carbonate content of the turbidites compared to the red mudstone very likely resulted from an above CCD origin of the turbidites and rapid deposition and burial that hindered dissolution. It is not unlikely that some carbonate was dissolved within the red mud and to a lower degree in the sandy-silty layers when $\mathrm{CO}_{2}$ was produced by oxic oxidation of organic matter (e.g. Archer et al., 1989).

The sandy-silty turbidites are interpreted to be deposited from low-density turbidity currents (LDTC) according to Mutti (1992). Such turbidites belong to Principal Facies Type D (laterally continuous shales with sandstone beds) grouped into turbidite facies F9a of Mutti (1992). Within this facies, turbidity currents have low erosive power as also indicated by rare to absent sole marks (cf. Mutti, 1992). A clear distinction between turbiditic and hemipelagic mud was impossible because of intense sediment mixing by burrowing organisms.

Presently, the red mudstone is effectively barren of organic matter. The low organic carbon content $(<0.1 \%)$ very likely represents organic compounds absorbed to mineral surfaces. In modern highly oxic settings, such as the central Pacific, completely oxidized brownish mud contains a similar amount of organic carbon that is adsorbed to mineral surfaces (Müller, 1975). This fraction of organic matter in sediments is not accessible to degradation (Sarmiento \& Gruber, 2006).

Adsorption of organic matter to mineral surfaces is influenced by several factors, among others, composition of organic matter and type of minerals (e.g. Ransom et al., 1998; Mayer, 1999; Arnason \& Keil, 2001). The mineral surface area is commonly approximated by the specific surface area (e.g. Rabitti et al., 1983). The ratio of organic carbon (OC) to specific surface area (SA) has been found to provide information about the oxygen exposure time of organic matter (Sarmiento \& Gruber, 2006). For 3 red mudstone samples the OC/SA ratio has been determined, and is $\sim 0.001$. Such a low value implies a considerably long oxygen exposure time of $c a 10^{2.8}$ years ( 630 years) when using the empirical relationship found by Sarmiento and Gruber (2006; fig. 6.4.4). For comparison, with increasing distance to coast and decreasing sedimentation rate an increasing oxygen exposure time of 40,63 and 158 years has been found for mud deposited 10,50 and $100 \mathrm{~km}$, respectively, offshore of Washington (Sarmiento \& Gruber, 2006).

Although the studied sediments are effectively barren of organic matter in the present state, they are completely bioturbated and the ichnofabrics indicate that the amount of benthic food was sufficient to support a burrowing fauna within the continuously accumulated hemipelagic mud. Decompacted, the bioturbated zone exceeds $10 \mathrm{~cm}$ in thickness (Table 1), a value typical of settings characterized by low sedimentation rate and low benthic food content (e.g. Wetzel, 1991, 2008; Uchman \& Wetzel, 2011). Similarly, the mixed layer occupies 2 to $3 \mathrm{~cm}$ in the uncompacted state, likewise a low value encountered in modern settings where little organic matter is buried (Wetzel, 1981, 2008).

Cross-cutting relationships indicate relative deep production of trace fossils within sediment and document that different intervals within the sea floor were occupied at different times. Shortly after deposition of a turbidite, its basal part and the buried sea floor underneath was explored by Scolicia producers (irregular echinoids); Scolicia appears to have been produced 
first and rather deep. The timing of Scolicia emplacement can be estimated by comparison with modern counterparts, but only for the large specimens. Deep-sea echinoids show a response in size and community structure about one year after the trophic situation has changed (Ruhl et al., 2014). Later, the same sediment level and the interval above becomes inhabited as indicated by Halopoa cross-cutting Scolicia. Deep-reaching Nereites may crosscut upper parts of Scolicia if turbidite sand is thin $(<1$ to $2 \mathrm{~cm})$. Thereafter, roughly an equilibrium occupation developed within the red mud (Fig. 9).

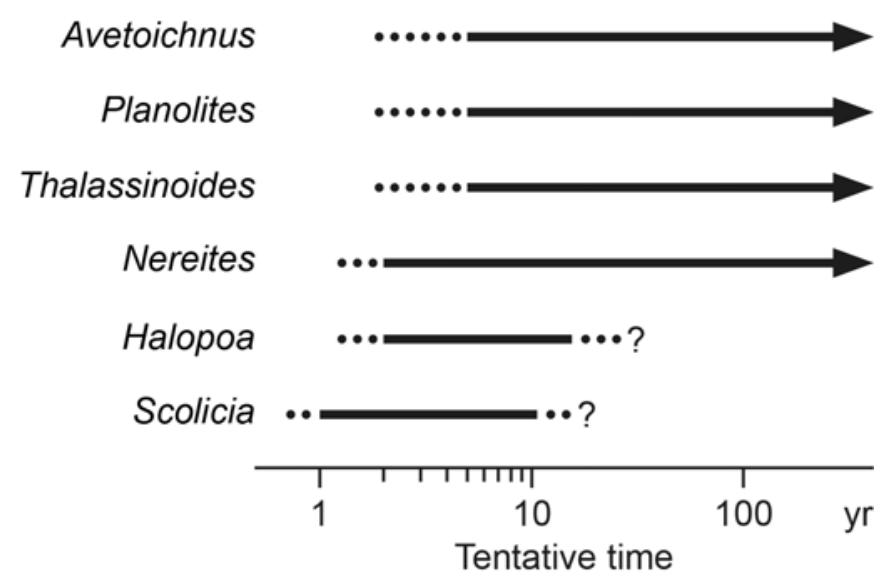

Fig. 9. Tentative timing of trace fossil production after turbidite deposition and during subsequent accumulation of 'red' mud; there is no time control, however. Scheme is based on observations in the modern deep-sea environment and crosscutting relationships. In the Recent, the response of Scolicia producers takes place within several months to about one year (for details, see text).

Idealized, in the red mud the ichnofabric is composed downward of an uppermost mixed layer, while below Avetoichnus, Planolites, and Nereites are present. All three may reach down to the boundary of the coarse interval, but do not penetrate deeply into the sand. The Thalassinoides-like burrows traverse the red mud into the sandy-silty turbidite or even deeper (Fig. 3). Halopoa and Scolicia occur within and below turbidites.

During the formation of a bed couplet consisting of turbidite sand and red mud, the availability of benthic food changed as indicated by the response of the burrowing organisms.

1 Enrichment of mud in burrows documents that producers fed on the sediment surface or selectively ingested fine-grained material enriched in organic matter.

2 Burrows recording purely subsurface sediment feeding such as Planolites are small and occur at low abundance implying low availability of nutritious food within the sediment. Small body size can be seen as an adaptation to a food-limited habitat (e.g. Seilacher, 1977; Wetzel \& Uchman, 2012; Ichino et al., 2015).

3 Based on the finding that Avetoichnus occurred in greyish sediments have organic matter enriched in the spiral surrounding the central tube, the Avetoichnus producers are interpreted to feed on the sediment surface and thus, to document at least seasonally available food on the sea floor (Uchman \& Rattazzi, 2011). In the case of oceanic red beds, the enlarged organic content in the spiral probably resulted in locally oxygen-deficient pore water and hence, in a steep geochemical gradient around the inhabited oxygenated central tube that was connected to the surface. Across this gradient, microbial activity is enhanced (e.g. Frindte et al., 2013). Flourishing microbes or their metabolic products could be used for nutrition.

4 Halopoa and Scolicia producers are deposit feeders that utilize organic matter buried by turbidites and thus, indicate the former presence of an organic-rich surface layer. Of particular interest is large Scolicia that in many instances completely cover a surface (Fig. 6). It suggests that the exploited interval must have contained a considerable amount of organic matter. Large Scolicia commonly exhibits guided meanders (Fig. 6). This behaviour 
is explained best by an optimized exploitation of benthic food (Seilacher, 1986). Since echinoid body size correlates with the nutrition value of the food (Kröncke, 2006), the presence of large Scolicia producers below the turbidites, indicates that nutritious benthic food was available. Consequently, the erosive power of the turbidity currents was too low to erode the organic-rich surface layer. Low erosion is also evidenced by the absence of sole marks. Furthermore, the Scolicia producers explored this layer shortly after turbidite deposition, because some specimens are cross-cut by Nereites occupying a shallower tier (Fig. 5).

5 Present-day Nereites irregularis producers live not too far above the redox potential discontinuity (RPD) where oxygen content of the pore water is lower. In the South China Sea, Nereites producers respond to enhanced deposition of organic matter due to seasonal upwelling while oxygen diffusion into the sediment is lowered (Wetzel, 2002, 2008, 2010). Then Nereites producers move upward, utilize surface sediment as additional food source and use fully oxygenated respiration water (Fig. 10).

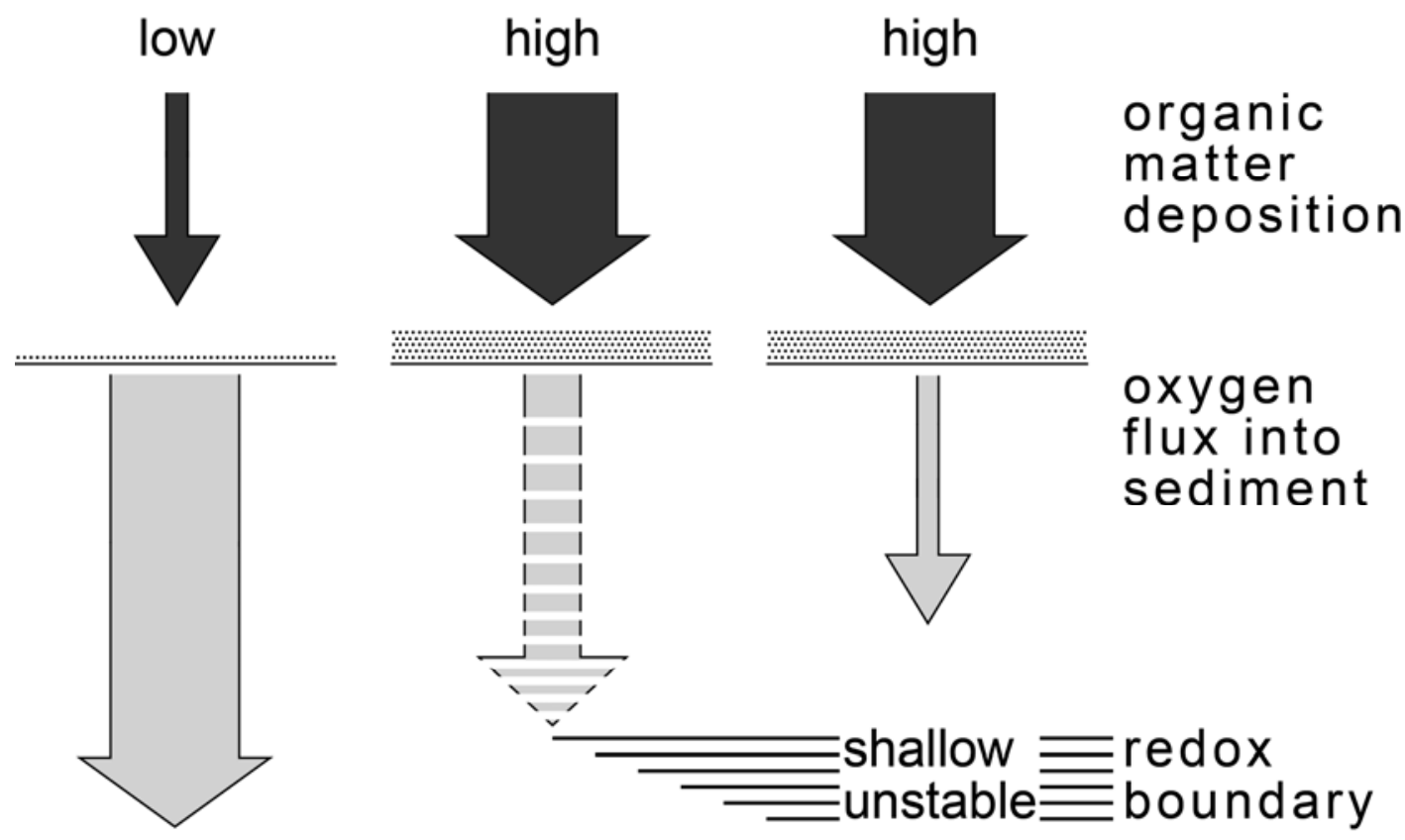

Fig. 10. Scheme for the response of Nereites producers to a pulse of organic matter deposition [adapted from Wetzel, 2010; redrawn for a setting without a clearly developed redox potential discontinuity (RPD)]. Depending on the reactivity of the organic matter, the shown development takes place in a few weeks to months. The given timing is based on recent observations in the South China Sea, where the Pinatubo 1991 ash was used as tracer and reference horizon as well.

In oxic settings, the RPD is not permanently developed. The conditions for Nereites producers are, thus, slightly different in the studied deposits (e.g. Haeckel et al., 2001). During seasons of high primary productivity and subsequent enhanced deposition of organic matter on the sea floor, $\mathrm{O}_{2}$ diffusion into the sediment is strongly diminished (e.g. Soetaert et al., 1996). Consequently, a low-oxygenated zone may develop within the sediment. Nereites producers probably exploited this interval. Alternatively, the presence of Nereites is related to organic matter that was entrained in turbidity currents and deposited due to its low density together with the fine fraction. This organic matter would facilitate the development of a temporary RPD or a low-oxygenated interval that attracted Nereites producers. 
These observations imply an environment characterized by seasonally fluctuating deposition of organic matter while the overall hemipelagic sedimentation rate was extremely low. Consequently, the sediment was oxic throughout (e.g. Burdige, 2006). When deposited on the sea floor, organic matter was incorporated into the surface mixed layer characterized by biodeformational structures. The formation of these structures was favoured by oxic oxidation of organic matter within the sediment providing $\mathrm{CO}_{2}$ that enhanced dissolution of carbonate tests (e.g. Aller, 1994), which might have arrived during blooms (see below). Water within these shells was delivered and the enlarged water content might have led to a softening of the substrate (e.g. Archer et al., 1989). Furthermore, the overall small size of a considerable proportion of the fauna in food-restricted settings favoured cryptobioturbation (cf. Leduc et al., 2015).

Due to slow sedimentation and continuous overturn of sediment within the surface mixed layer, oxygen exposure time was comparatively long and thus, burial rate of organic matter very low as found in modern settings (cf. Müller \& Suess, 1979). Furthermore, the amount of nutritious organic matter such as proteins and polysaccharides decreases with increasing oxygen exposure time (Nierop et al., 2017). Thus, quality and quantity of organic matter buried and being available for sediment feeding organisms was low as documented, for instance, by the rather small Planolites and the Thalassinoides-like burrows. Other trace fossil producers were more efficient in utilizing organic matter temporarily arriving on the sea floor as indicated by their size being similar to settings not restricted in food resources (Wetzel, 2008; Uchman \& Wetzel, 2011; Wetzel \& Uchman, 2012). Avetoichnus and Nereites producers were able to immediately respond to the arrival of organic matter, while being very sensitive to oxygenation/redox changes (Wetzel, 2002). Scolicia producers were specialized in the exploitation of the buried sea floor, while Halopoa producers explored both turbidite sand and the sea floor sediment underneath.

The weak expression of tiering is another indication of the variable organic matter input in oxic settings. Fluctuating organic matter deposition stimulated organisms to move upwards and downwards and to remain close to the temporary geochemically favourable zones that are lower in oxygen. Depth of these zones varied during a year, triggered by arrival and disappearance of organic material on the sea floor (e.g. Wetzel, 2008). Additionally, interannual variations were very likely as observed in modern oceans (e.g. Lutz et al., 2007).

The organic matter utilized by the trace fossil producers became oxidized later. For organicrich deposits, the subsequent, downward expanding oxidation of organic matter has been called 'burn down' (Jung et al., 1997). Several factors affect burn-down; such as, oxygen content of bottom water, sedimentation rate, life time of organic matter deposited during burndown and bioturbation intensity and depth (e.g. Jung et al., 1997). A sensitivity analysis demonstrated that sedimentation rate is of major importance; if bottom water is fully oxygenated, at sedimentation rates lower than 1 to $2 \mathrm{~cm} / \mathrm{kyr}$, burial of elevated concentrations of organic matter is improbable (e.g. Jung et al., 1997; Löwemark et al., 2006). This result matches earlier findings of Müller and Suess (1979) that sedimentation rate is the main factor controlling the burial of organic matter in oxygenated settings.

Also the several centimetres thick turbidites became completely oxidized, but degradation of organic matter within and underneath turbidites was boosted by deep burrowing sea urchins that are known for efficient sediment turnover (e.g. Lohrer et al., 2004). Furthermore, rather deep-penetrating organisms that produced the Thalassinoides-like burrows facilitated deep bioirrigation. Consequently, oxidation and 'burn down' of organic matter was enhanced by bioturbation. 
Over the long term, organic matter arrival on the sea floor fluctuated as indicated by either absent, small or large Scolicia representing times of very low, low and considerable amount of organic matter availability, respectively. The timing of these fluctuations cannot be deciphered in detail because the studied section is tectonically dismembered into a set of slices and biostratigraphic information is too sparse (Uchman, 2008).

\section{DISCUSSION}

Based on ichnofabrics and trace fossils, the environmental situation during the formation of oceanic red beds in the Carpathians' foredeep during the Eocene can be inferred, but it is based completely on analogies from the rock record and modern counterparts. Of major importance is the presence of large Scolicia, whose producers exploited lower bedding planes and hence, document presence of high-quality benthic food, while small Scolicia is sparse and hence, indicates a less favourable trophic situation. Similar observations are made in the modern deep-sea sediments of the South China Sea; the more nutritious the organic matter, the larger the Scolicia (Wetzel, 2008). A similar relationship has been found for burrowing echinoids in modern North Sea sediments (Kröncke, 2006) and for surface-feeding echinoids in the NE Pacific (Ruhl et al., 2014).

The presence of Scolicia demonstrates that the deposition of distal low-erosive turbidites is essential for deciphering the environmental conditions under which oceanic red beds formed. They interrupted continuous sediment accumulation and bioturbation that would otherwise result in a rather uniform ichnofabric dominated by deeply produced trace fossils (Werner \& Wetzel, 1982). Distal turbidites preserve frozen tiers underneath, little affected by erosion and thus, record the former presence of an organic-rich surface layer that was exploited by large Scolicia producers.

At first glance, the oceanic red beds appear to represent sediments that were low in organic matter as evidenced by small-sized Planolites and the Thalassinoides-like burrows. The observed trace fossil association is quite similar in several instances to those described from oceanic red beds by Leszczyński (1993), Mikuláš et al. (2009) and Reolid et al. (2015). The sediments are completely bioturbated, but trace fossils are of a small size and do not completely form the fabric while the proportion of biodeformational structures is high. The composition of the trace fossil associations, however, shows some differences, in particular Chondrites and Zoophycos occur in other oceanic red beds, but are absent in the studied intervals. The producers of these trace fossils utilize chemosymbiosis or a cache, respectively. In both cases, locally reducing conditions should have existed within the sediment and hence, imply the former presence of organic matter. The absence of these traces in the studied deposits could indicate stronger oxidizing conditions than in the other ORBs.

Food-limited long-term stable deposits are suitable for graphoglyptid producers (e.g. Seilacher, 1977). However, graphoglyptids have not been observed in the studied sections. The absence of graphoglyptids is in agreement with the presence of large Scolicia and Nereites that implies seasonally pronounced deposition of organic matter on the sea floor. During such periods, epibenthic 'bulldozers' could have been potentially present. Both, ploughing 'bulldozers' as well as upward and downward moving Nereites producers probably disturbed the habitat of graphoglyptid producers and hence, it is probable that graphoglyptids were not produced. This is obvious on lower surfaces of turbidites that are not completely covered with Halopoa and/or Scolicia. Additionally, deep penetrating Scolicia would overprint previously formed graphoglyptids. The suggested antagonism of Nereites and Scolicia production counteracting the formation of graphoglyptids is supported by 
observations of Leszczyński (1993; table 1), who found that graphoglyptids are only present in turbidite-red marl successions if these two traces are absent.

This finding matches observations in modern settings, where graphoglyptids appear to be restricted to food-limited areas not affected by strong seasonality of organic matter deposition (Wetzel, 2010). There is, however, no detailed study of graphoglyptids in modern deep-sea sediments. Consequently, the absence of graphoglyptids appears to support the inference that the depositional setting of the studied oceanic red beds was affected by periods of enhanced deposition of organic matter on the sea floor. The low food content within the sediment was mainly due to a very low sedimentation rate that resulted in a low burial rate of organic matter (e.g. Müller \& Suess, 1979; Burdige, 2006). The low sedimentation rate may explain the peculiar finding that a sediment low in organic matter formed in an area where seasonally considerable amounts of organic matter arrived on the sea floor.

Another explanation for the absence of graphoglyptids could be related to the hypothesis that particle size diversity correlates with species diversity in modern deep-sea settings (Etter \& Grassle, 1992). Well-sorted continuously accumulating mud would not support a diverse fauna. In this case, dissolution of microfossils shells was rather rapid and recurrence time of turbidites rather long. A low adaptation of the burrowing fauna is indicated by the low extent of vertical mixing of turbidites ( $<1$ to $2 \mathrm{~cm}$; Fig. 3; Wetzel, 1991).

Rather deep bioturbation and a low sedimentation rate facilitated 'burn down' of previous deposited organic matter. Under such conditions even organic matter buried by turbidites became oxidized. 'Burn down' occurs even if seasonally considerable amounts of organic matter arrived on the sea floor as observed today. For example, below the CCD in the deepest part of the South China Sea ( $>4300 \mathrm{~m}$ in water depth), an organic-rich mud turbidite was deposited ca 350 years ago (Wetzel \& Unverricht, 2013). The mud turbidite showed 'burn down' features while its colour changed from dark green to pale-brownish. In the area affected by seasonally high organic-matter flux due to upwelling, the 'burn down' reached $2 \mathrm{~cm}$ downwards, whereas in low productive areas not affected by upwelling, the 'burn down' depth is in the range of 4 to $6 \mathrm{~cm}$.

For the studied oceanic red beds formed within an accretionary wedge system two aspects need be considered. First, fuelling of presumably seasonally high primary production and, second, low sedimentation rate within deep-sea trench setting in front of an evolving orogen. Low sedimentation rate in front of the evolving orogen (e.g. Oszczypko, 1999) may be caused by flooding of the source areas. In turn, this area might have provided nutrients during EarlyMiddle Eocene flooding of the adjacent Central West Carpathians and Alps (cf. Kázmér et al., 2003). In other orogens, cascading piggy-back basins might have formed along developing overthrusts. A basin near the orogen commonly acts as sediment trap and distal basins experience sediment starvation as observed today offshore of California (e.g. Schwalbach \& Gorsline, 1985). High primary production north of the evolving Alpine-Carpathian orogen was probably fuelled by upwelling induced by main wind directions parallel or slightly oblique to it during Paleogene times as suggested by modelling results (e.g. Parrish \& Curtis, 1982). In addition, fluvial dissolved load originating in the developing orogen might have provided nutrients.

\section{CONCLUSIONS}

Oceanic red beds formed in an oxic setting and are effectively barren of organic matter in the present state below the calcite compensation depth (CCD). Trace fossils and ichnofabrics are 
very suitable for deciphering the environmental setting as macrofossil and microfossil remains are sparse to absent. Trace fossils indicate that food in the benthic environment was sufficient to support a weakly tiered burrowing fauna that penetrated to depths of up to $10 \mathrm{~cm}$, comparable to those in modern sediments.

Organic matter deposition on the sea floor fluctuated seasonally as evidenced by the trace fossils Nereites and Scolicia. Scolicia produced by sea urchins may cover the lower surface of distal low-erosive turbidites that preserve the nearly complete bioturbated zone underneath. Scolicia is large ( $>4 \mathrm{~cm}$ diameter) and may cover a whole surface while showing guided meanders. Large Scolicia and its guided meanders are indicative of the presence of considerable amounts of nutritious organic matter. Consequently, the sea urchins exploited the buried sea floor shortly after turbidite deposition. Such beds form packages of 6 to 12 turbidite red-mudstone couplets.

Modern producers of Nereites irregularis live in deep-sea sediment above the redox potential discontinuity (RPD) where pore water oxygen content is somewhat lowered. They respond rapidly to the seasonal deposition of organic matter on the sea floor and utilized it as an additional food source and hence, move upward and downward.

Seasonally deposited organic matter probably supported bulldozing organisms on the sea floor, that in cooperation with Nereites producers counteracted the formation of graphoglyptids. In modern deep-sea settings graphoglyptids have so far only been reported from areas affected by weak seasonality. Furthermore, the low particle size diversity of the continuously accumulating mud favours the presence of a low-diversity fauna.

In red mudstone, trace fossils exhibit special adaptations to the food-restricted deep-sea environment, such as small size (e.g., Planolites and Thalassinoides-like burrows). Also, the vertical extent of the bioturbated zone is small, $c a 10$ to $12 \mathrm{~cm}$ (after decompaction). These observations match findings in modern, slowly accumulating, food-limited deep-sea settings.

Sedimentary organic matter experienced later oxidation even if high amounts arrived seasonally while sedimentation rate was very low and thus, oxygen exposure time of the organic matter was considerably long ( $>500$ to 700 years). Oxygen exposure times provide a minimum estimate for the recurrence time of turbidites. Low sedimentation rates in combination with bioturbation facilitated oxidation of organic matter buried by turbidites because the burrowing organisms enhanced flux of oxygen into sediment while pumping oxygenated respiration water into considerable sediment depth. In this way, the deposition of organic matter facilitated its latter degradation and final absence.

Seasonally high delivery of organic matter was probably provided by upwelling, while low sedimentation rate is due to the distal position of the depositional area within a convergent tectonic regime where temporarily developed depressions closer to land probably acted as sediment traps.

\section{ACKNOWLEDGEMENTS}

Carbonate and organic matter content was measured by R. Strunk (Geography, Department of Environmental Sciences, University of Basel), specific surface area was determined by K. Schweinar (Institute for Clay and Interface Mineralogy, RWTH Aachen, Germany). A. Reisdorf (Basel) prepared the figures. Financial support was provided by the Swiss National Fund (grant 200021_169042/1 to AW). AU was supported by the Jagiellonian University (DS funds). All these contributions are gratefully acknowledged. 


\section{REFERENCES}

Aller, R.C. (1994) Bioturbation and remineralization of sedimentary organic matter: effects of redox oscillation. Organic Geochemistry, 114, 331-345.

Archer, D., Emerson, S. and Reimers, C. (1989) Dissolution of calcite in deep-sea sediments: $\mathrm{pH}$ and $\mathrm{O}_{2}$ microelectrode results. Geochimica et Cosmochimica Acta, 53, 2831-2845.

Arnason, T.S. and Keil, R.G. (2001) Organic-mineral interactions in marine sediments studied using density fractionation and X-ray photoelectron spectroscopy. Organic Geochemistry, 32, 1401-1415.

Bernaola, G., Baceta, J.I., Payros, A., Orue-Etxebarria, X. and Apellaniz, E. (Editors) (2006) The Paleocene and lower Eocene of the Zumaia section (Basque Basin). Climate and Biota of the Early Paleogene 2006. Post-Conference Field Trip Guidebook, Bilbao, $82 \mathrm{pp}$.

Bertier, P., Schweinar, K., Stanjek, H., Ghanizadeh, A., Clarkson, C.R., Busch, A., Kampman, N., Prinz, D., Amann-Hildenbrand, A., Krooss, B.M. and Pipich, V. (2016) On the use and abuse of $\mathrm{N}_{2}$ physisorption for the characterization of the pore structure of shales. The Clay Minerals Society Workshop Lectures Series, 21, 151-161.

Bromley, R.G., Asgaard, U. and Jensen, M. (1997) Experimental study of sediment structures created by a spatangoid echinoid, Echinocardium mediterraneum. Proceedings of the Geologists' Association, 108, 183-189.

Bromley, R.G. and Ekdale, A.A. (1986) Composite ichnofabrics and tiering of burrows. Geological Magazine, 123, 59-65.

Bryant, W.R., Bennett, R.H. and Katherman, C.F. (1981) Shear strength, consolidation, porosity, and permeability of oceanic sediments. In: The Oceanic Lithosphere (Ed. C. Emiliani), pp. 797-809. Wiley, New York.

Buatois, L. and Mangáno, M.G. (2011) Ichnology: Organism-Substrate Interactions in Space and Time. Cambridge University Press, Cambridge, 358 pp.

Burdige, D.J. (2006) Geochemistry of Marine Sediments. Princeton University Press, 609 pp.

Dominik, J. (1977) A mineralogical-petrographical study of variegated shales from the Magura nappe (the Carpathians). Prace Mineralogiczne (Warszawa), 53, 1-86.

Etter, R.J. and Grassle, J.F. (1992) Patterns of species diversity in the deep sea as function of sediment particle size diversity. Nature, 360, 576-578.

Frindte, K., Eckert, W., Attermeyer, K. and Grossart, H.-P. (2013) Internal wave-induced redox shifts affect biogeochemistry and microbial activity in sediments: a simulation experiment. Biogeochemistry, 113, 423-434.

Haeckel, M., Beusekom, J.V., Wiesner, M.G. and König, I. (2001) The impact of the 1991 Mount Pinatubo tephra fallout on the geochemical environment of the deep-sea sediments in the South China Sea. Earth and Planetary Science Letters, 193, 151-166.

Haese, R. (2006) The biogeochemistry of iron. In: Marine Geochemistry (Eds H.D. Schulz and M. Zabel), $2^{\text {nd }}$ edn, pp. 241-270. Springer, Berlin, Heidelberg, New York.

Hesse, R. (1975) Turbiditic and non-turbiditic mudstone of Cretaceous flysch sections of the East Alps and other basins. Sedimentology, 22, 387-416. 
Hu, X., Scott, R.W., Cai, Y., Wang, C. and Melinte-Dobrinescu, M.-C. (2012 a) Cretaceous oceanic red beds (CORBs): different time scales and models of origin. Earth Science Reviews, 115, 217-248.

Hu, X., Wagreich, M. and Yilmaz, O. (Editors) (2012b) Marine Rapid Environmental/ Climatic Change in the Cretaceous Greenhouse World. Cretaceous Research, 38, 112 p.

Hu, X., Wang, C., Scott, R.W., Wagreich, M. and Jansa, L. (Editors) (2009) Cretaceous Oceanic Red Beds: Stratigraphy, Composition, Origins, and Paleoceanographic and Paleoclimatic Significance. SEPM Special Publication, 91, 276 p.

Hund, F. (1966) Abhängigkeit der Farbe roter Eisen(III)-oxyde von Teilchengrösse und Teilchengrösseverteilung. Chemie-Ingenieur-Technik, 38, 423-428.

Ichino, M.C., Clark, M.R., Drazen, J.C., Jamieson, A., Jones, D.O.B., Martin, A.P., Rowden, A.A., Shank, T.M., Yancey, P.H. and Ruhl, H.A. (2015) The distribution of benthic biomass in hadal trenches: a modelling approach to investigate the effects of vertical and lateral organic matter transport to the seafloor. Deep-Sea Research I, 100, $21-33$.

Jung, M., Ilmberger, J., Mangini, A. and Emeis, K.-C. (1997) Why some Mediterranean sapropels survived burn-down (and others did not). Marine Geology, 141, 51-60.

Kázmér, M., Dunkl, I., Frisch, W., Kuhlemann J. and Ozsvárt, P. (2003) The Palaeogene forearc basin of the Eastern Alps and Western Carpathians: subduction erosion and basin evolution. Journal of the Geological Society, London, 160, 413-428.

Knaust, D. and Bromley, R.G. (2012) Trace Fossils as Indicators of Sedimentary Environments. Elsevier, Amsterdam, Developments in Sedimentology, 64, 924 pp.

König, I., Drodt, M., Suess, E. and Trautwein, A.X. (1997) Iron reduction through the tangreen color transition in deep-sea sediments. Geochimica et Cosmochimica Acta, 61, $1679-1683$.

Kristinof, R.E. and Marketos, G. (2016) Geotechnical characteristics of a high-porosity deep-sea clay sample retrieved from within a giant scour and its implications for geological history. Quarterly Journal of Engineering Geology and Hydrogeology, 49, 154-169.

Kröncke, I. (2006) Structure and function of macrofaunal communities influenced by hydrodynamically controlled food availability in the Wadden Sea, the open North Sea, and the deep-sea. A synopsis. Senckenbergiana maritima, 36, 123-164.

Ksiązkiewicz, M. (1962) Geological Atlas of Poland. Stratigraphic and Facial Problems. Fasc. 13 - Cretaceous and Early Tertiary in the Polish External Carpathians. Institute of Geological Sciences, Warszawa.

Leduc, D., Rowden, A.A., Glud, R.N., Wenzhöfer, F., Kitazato, H. and Clark, M.R. (2016) Comparison between infaunal communities of the deep floor and edge of the Tonga Trench: possible effects of differences in organic matter supply. Deep-Sea Research I, 116, 264-275.

Leszczyński, S. (1993) Ichnocoenosis versus sediment colour in Upper Albian to Lower Eocene turbidites, Guipúzcoa province, northern Spain. Palaeogeography, Palaeoclimatology, Palaeoecology, 100, 251-265.

Leszczyński, S. and Uchman, A. (1991) To the origin of variegated shales from flysch of the Polish Carpathians. Geologica Carpathica, 42, 279-289. 
Leszczyński, S. and Uchman, A. (1993) Biogenic structures of organic-poor sediments: examples from the Paleogene variegated shales, Polish Outer Carpathians. Ichnos, 2, 267-275;

Li, X. and Cai, Y. (2013) Constraining the colouration mechanisms of Cretaceous Oceanic Red Beds using diffuse reflectance spectroscopy. Cretaceous Research, 46, 257-266.

Lohrer, A.M., Trush, S.F. and Gibbs, M.M. (2004) Bioturbators enhance ecosystem function through complex biogeochemical interactions. Nature, 431, 1092-1095.

Löwemark, L., Lin, Y., Chen, H.-F., Yang, T.-N., Beier, C., Werner, F., Lee, C.-Y., Song, S.-R. and Kao, S.-J. (2006) Sapropel burn-down and ichnological response to late Quaternary sapropel formation in two ca. $400 \mathrm{ky}$ records from the eastern Mediterranean Sea. Palaeogeography, Palaeoclimatology, Palaeoecology, 239, 406425 .

Lutz, M.J., Caldeira, K., Dunbar, R.B. and Behrenfeld, M.J. (2007) Seasonal rhythms of net primary production and particulate organic carbon flux describe biological pump efficiency in the global ocean. Journal of Geophysical Research, 112, C 10011, 1-26.

Mayer, L.M. (1999) Extent of coverage of mineral surfaces by organic matter in marine sediments. Geochimica et Cosmochimica Acta, 63, 207-215.

McIlroy, D. (2004) Some ichnological concepts, methodologies, applications and frontiers, In: The Application of Ichnology to Palaeoenvironmental and Stratigraphic Analysis (Ed. D. McIlroy), Geological Society London, Special Publication, 228, 3-27.

Mikuláš, R., Skupien, P., Bubík, M. and Vašícek, Z. (2009) Ichnology of the Cretaceous oceanic red beds (Outer Western Carpathians, Czech Republic). Geologica Carpathica, 60, 233-250.

Müller, P.J. (1975) Diagenese stickstoffhaltiger organischer Substanzen in oxischen und anoxischen marinen Sedimenten. "Meteor"-Forschungsergebnisse, Reihe C, 22, 1-60.

Müller, P.J. and Suess, E. (1979) Productivity, sedimentation rate and sedimentary organic matter in the oceans. I. Organic carbon preservation. Deep-Sea Research, 26, 1347 1362.

Mutti, E. (1992) Turbidite Sandstones. AGIP, San Donato Milanese, 275 pp.

Nierop, K.G.J., Reichart, G.-J., Veld, H. and Damsté, J.S.S. (2017) The influence of oxygen exposure time on the composition of macromolecular organic matter as revealed by surface sediments on the Murray Ridge (Arabian Sea). Geochimica et Cosmochimica Acta, 206, 40-56.

Oszczypko, N. (1991) Stratigraphy of the Palaeogene deposits of the Bystrica Subunit (Magura Nappe, Polish Outer Carpathians). Bulletin of the Polish Academy of Sciences, Earth Sciences, 39, 415-431.

Oszczypko, N. (1999) From remnant oceanic basin to collision-related foreland basin-a tentative history of the Outer Western Carpathians. Geologica Carpathica, 50, 161-163.

Oszczypko, N., Malata, E., Bąk, K., Kędzierski, M. and Oszczypko-Clowes, M. (2005) Lithostratigraphy and biostratigraphy of the Upper Albian-Lower/Middle Eocene flysch deposits in the Bystrica and Rača subunits of the Magura Nappe (Beskid Wyspowy and Gorce Ranges; Poland). Annales Societatis Geologorum Poloniae, 75, 27-69.

Oszczypko, N., Ślączka, A., Oszczypko-Clowes, A. and Olszewska, B. (2015) Where was the Magura Ocean. Acta Geologica Polonica, 65, 319-344. 
Parrish, J.T. and Curtis, R.L. (1982) Atmospheric circulation, upwelling, and organic-rich rocks in the Mesozoic and Cenozoic. Palaeogeography, Palaeoclimatology, Palaeoecology, 40, 31-66.

Pickering, K.T., Hiscott, R.N. and Hein, F.J. (1989) Deep Marine Environments: Clastic Sedimentation and Tectonics. Unwin Hyman, London, 416 pp.

Rabitti, S., Boldrin, A. and Vitturi, L.M. (1983) Relationships between surface area and grain size in bottom sediments. Journal of Sedimentary Petrology, 53, 665-667.

Raiswell, R. and Canfield, D.E. (2012) The iron biogeochemical cycle past and present. Geochemical Perspectives, 1, 1-220.

Ransom, B., Ki, D., Kastner, M. and Wainright, S. (1998) Organic matter preservation on continental slopes: importance of mineralogy and surface area. Geochimica et Cosmochimica Acta, 62, 1329-1345.

Reolid, M., Rivas, P. and Rodríguez-Tovar, F.J. (2015) Toarcian ammonitico rosso facies from the South Iberian Paleomargin (Betic Cordillera, southern Spain): paleoenvironmental reconstruction. Facies, 61, 22: 1-26.

Roden, E.E. and Zachara, J.M. (1996) Microbial reduction of crystalline iron (III) oxides: influence of oxides surface area and potential for cell growth. Environmental Science and Technology, 30, 1618-1628.

Ruhl, H.A., Bett, B.J., Hughes, S.J.M., Alt, C.H.S., Ross, E.J., Lampitt, R.S., Pebody, C.A., Smith, K.L. and Billett, D.S.M. (2014) Links between deep-sea respiration and community dynamics. Ecology, 95, 1651-1662.

Sarmiento, J.L. and Gruber, L. (2006) Ocean Biogeochemical Dynamics. Princeton University Press, 503 pp.

Schäfer, W. (1956) Wirkungen der Benthos-Organismen auf den jungen Schichtverband. Senckenbergiana lethaea, 37, 183-263.

Schultheiss, P.J. and Gunn, D.E. (1985) The Permeability and Consolidation of Deep-Sea Sediments. Institute of Oceanographic Sciences, Wormley, Report 201, 94 pp.

Schwalbach, J.R. and Gorsline, D.S. (1985) Holocene sediment budgets for the basins of the California continental borderland. Journal of Sedimentary Petrology, 55, 829-842.

Seilacher, A. (1977) Pattern analysis of Paleodictyon and related trace fossils. In: Trace Fossils 2 (Eds T.P. Crimes and J.C. Harper), Geological Journal, Special Issue, 9, 289-334.

Seilacher, A. (1986) Evolution of behavior as expressed in marine trace fossils. In: Evolution of Animal Behavior - Paleontological and Field Approaches (Eds M.H. Nitecki and J.A. Kitchell.), pp. 62-87. Oxford University Press, New York.

Soetaert, K., Herman, P.M.J. and Middelburg, J.J. (1996) Dynamic response of deep-sea sediments to seasonal variations: a model. Limnology and Oceanography, 41, 16511668 .

Uchman, A. (1998) Taxonomy and ethology of flysch trace fossils: revision of the Marian Książkiewicz collection and studies of complementary material. Annales Societatis Geologorum Poloniae, 68, 105-208. 
Uchman, A. (2008) Stop 11 - Słopnice - Ropianka Formation (Senonian-Palaeocene) and Variegated Shale (Eocene). In: Ichnological Sites of Poland: The Holy Cross Mountains and the Carpathian Flysch. The Second International Congress on Ichnology, Cracow, Poland, August 29-September 8, 2008 (Eds G. Pieńkowski and A. Uchman), PreCongress and Post-Congress Field Trip Guidebook. Polish Geological Institute, Warszawa, pp. 136-138.

Uchman, A. and Rattazzi, B. (2011) The new complex helical trace fossil Avetoichnus luisae igen. n. et isp. n. from the Cainozoic deep-sea sediments of the Alpine realm: a nongraphoglyptid mid-tier ichnion. Neues Jahrbuch für Geologie und Paläontologie, Abhandlungen, 260, 319-330.

Uchman, A. and Wetzel, A. (2011) Deep-sea ichnology: the relationships between depositional environment and endobenthic organisms. In: Deep-Sea Sediments (Eds H. Hüneke and T. Mulder), Developments in Sedimentology, 63, 517-556.

Wagreich, M., Hu, X. and Sageman, B. (Editors) (2011) Causes of oxic - anoxic changes in Cretaceous marine environments and their implications for Earth systems. Sedimentary Geology, 235, 132 p.

Wagreich, M. and Krenmayr, H.-G. (2005) Upper Cretaceous oceanic red beds (CORB) in the Northern Calcareous Alps (Nierental Formation, Austria): slope topography and clastic input as primary controlling factors. Cretaceous Research, 26, 57-64.

Wan, X. and Sarti, M. (Editors) (2005) Cretaceous oceanic red beds and land-ocean interaction. Cretaceous Research, 26, 156 p.

Werner, F. and Wetzel, A. (1982) Interpretation of biogenic structures in oceanic sediments. Bulletin de l' Institut de Géologie du Bassin d'Aquitaine, 31, 275-288.

Wetzel, A. (1981) Ökologische und stratigraphische Bedeutung biogener Gefüge in quartären Sedimenten am NW-afrikanischen Kontinentalrand. "Meteor" Forschungs-Ergebnisse, Reihe C, 34, 1-47.

Wetzel, A. (1984) Bioturbation in deep-sea fine-grained sediments: influence of sediment texture, turbidite frequency and rates of environmental change. In: Fine-Grained Sediments: Deep-Water Processes and Facies (Eds D.A.V. Stow and D.J.W. Piper), Geological Society London Special Publications, 15, 595-608.

Wetzel, A. (1991) Ecologic interpretation of deep-sea trace fossil communities. Palaeogeography, Palaeoclimatology, Palaeoecology, 85, 47-69.

Wetzel, A. (2002) Modern Nereites in the South China Sea - ecological association with redox conditions in the sediment. Palaios, 17, 507-515.

Wetzel, A. (2008) Recent bioturbation in the deep South China Sea: a uniformitarian ichnologic approach. Palaios, 23, 601-615.

Wetzel, A. (2010) Deep-sea ichnology: observations in modern sediments to interpret fossil counterparts. Acta Geologica Polonica, 60, 125-138.

Wetzel, A. and Uchman, A. (1998 a) Biogenic sedimentary structures in mudstones - an overview. In: Shales and Mudstones I (Eds J. Schieber, W. Zimmerle and P. Sethi), pp. 351-369. Schweizerbart, Stuttgart.

Wetzel, A. and Uchman, A. (1998 b) Deep-sea benthic food content recorded by ichnofabrics: a conceptual model based on observations from Paleogene flysch, Carpathians, Poland. Palaios, 13, 533-546. 
Wetzel, A. and Uchman, A. (2001) Sequential colonization of muddy turbidites in the Eocene Beloveža Formation, Carpathians, Poland. Palaeogeography, Palaeoclimatology, Palaeoecology, 168, 171-186.

Wetzel, A. and Uchman, A. (2012) Hemipelagic and pelagic basin plains. In: Trace Fossils as Indicators of Sedimentary Environments (Eds D. Knaust and R.G. Bromley), Developments in Sedimentology, 64, 673-701.

Wetzel, A. and Unverricht, D. (2013) A muddy megaturbidite in the deep central South China Sea deposited $\sim 350$ yrs BP. Marine Geology, 346, 91-100.

Winkler, W. (1993) Control factors on turbidite sedimentation in a deep-sea trench setting. The example of the Schlieren Flysch (Upper Maastrichtian-Lower Eocene, Central Switzerland). Geodinamica Acta, 6, 81-102. 